\title{
Acute anti-inflammatory activity of ethanolic extract of leaves of Leucas indica by carrageenan induced paw oedema in wistar albino rats
}

\author{
Chandrashekar R.*, S. N. Rao
}

Department of Pharmacology, Yenepoya Medical College, Yenepoya University, Derlakatte, Mangalore 575018, Karnataka, India

\section{Received: 1 March 2013 \\ Revised: 8 April 2013 \\ Accepted: 9 April 2013

\author{
*Correspondence to: \\ Dr. Chandrashekar R., \\ Email: \\ chandumoon47@gmail.com
}

(C) 2013 Chandrashekar R et al. This is an open-access article distributed under the terms of the Creative Commons Attribution License, which permits unrestricted use, distribution, and reproduction in any medium, provided the original work is properly cited.

\begin{abstract}
Background: Inflammation is basically a defense phenomenon but can lead to serious pathological conditions. It is treated by various agents with good to moderate success because of both considerable toxicity and side effects. There are various mediators to cause an inflammatory reaction that can contribute to the associated symptoms and tissue injury. Even though non steroidal antiinflammatory drugs are the most commonly prescribed drugs in the world, their use as anti-inflammatory agents continues to be principally limited by their undesired side effects. Hence, the traditional medical practitioners and scientists are turning towards Indian System of Medicine (ISM).

Methods: Dried powdered leaves of Leucas indica were subjected to solvent extraction by using $90 \%$ ethanol. Based on acute oral toxicity study according to Organization for Economic Cooperation and Development (OECD) guidelines No. 423, three doses of the test drug $75,150 \& 300 \mathrm{mg} / \mathrm{kg}$ were selected and subjected to preclinical anti-inflammatory screening by carrageenin induced paw oedema in Wistar Albino rats.

Results : Oral administration of Ethanolic Extract Of Leaves Of Leucas Indica (EELLI) at doses of $150 \mathrm{mg} / \mathrm{kg}$ and $300 \mathrm{mg} / \mathrm{kg}$ showed significant antiinflammatory activity $52.58 \%(\mathrm{p}<0.01)$ and $36.87 \% \quad(\mathrm{p}<0.05) \quad$ respectively compared to control.

Conclusion: Even though oral administration of EELLI has shown significant anti-inflammatory activity, further studies are required to evaluate its comprehensive analysis including quantitative / semi quantitative analysis, characterize its chemical structure and assess its pharmacotherapeutic activities with exact mechanism of action as an anti-inflammatory agent.
\end{abstract}

Keywords: Anti-inflammatory activity, Leucas indica, Carrageenin, Indomethacin

\section{INTRODUCTION}

Inflammation is a biological response of living tissue to harmful stimuli, pathogens, irritants characterized by redness, warmth, swelling and pain. Inflammation is a common manifestation of infectious diseases like leprosy, tuberculosis, syphilis, asthma, inflammatory bowel syndrome, nephritis, vasculitis, celiac diseases, autoimmune diseases etc. Anti-inflammatory drugs like Non Steroidal Anti-Inflammatory Drugs (NSAIDs) are used to reduce pain and inflammation. But these agents carry the risk of gastro-intestinal, cardiovascular and other toxicities on prolonged use. ${ }^{1}$ For this reason, there is still need for newer anti-inflammatory drugs having less severe side. Recently more interest is shown in alternative and natural drugs for treatment of various diseases, but there is lack of scientific data. Hence the background and objective of this study was to carry out preclinical screening acute anti-inflammatory activity of Ethanolic Extract of Leaves of Leucas indica (EELLI) by carrageenan induced paw oedema in Wistar Albino rats.

\section{METHODS}

Institutional Animal Ethical Committee approval was obtained from Yenepoya University, Derlakatte, Mangalore, Karnataka, India, before conducting the experiments dated $6^{\text {th }}$ May 2010, Ref Ph.D 1/ 2010).

\section{Plant material}

The whole plant was collected from rural region of Manjanady, in Mangalore region, Karnataka, India, in the month of June - August 2010. It was authenticated by 
(Prof) Dr. Krishna Kumar G., Chairman, Dept of Applied Botany, Mangalore University, Mangalore, Karnataka, India. The herbarium of the plant (voucher specimen no YU/LI/2010) has been deposited at Museum of Department of Pharmacology, Yenepoya Medical College, Yenepoya University, Mangalore, Karnataka, India.

\section{Extraction}

Leaves of Leucas indica were carefully separated, cleaned, shade dried, mechanically grinded and coarsely powdered. The coarse powder was subjected to solvent extraction in Soxhlet extractor using 90\% ethanol. The ethanolic extract was concentrated by vacuum distillation to dryness; the yield obtained was $15.5 \% \mathrm{w} / \mathrm{w}$ with respect to dried leaf. The obtained yield was stored in a desiccator. A suspension of the extract prepared in $1 \%$ gum acacia was used in present study.

\section{Sample Size, Grouping and Dose of the Drugs}

Animals were divided into 5 groups (Control, Standard \& 3 groups of Test drug) containing 10 animals, making a total number of 50 animals.

\section{Drugs and Chemicals}

The Standard Indomethacin was obtained from our institutional pharmacy and $1 \%$ gum acacia from Department of Pharmacology, YMC, Mangalore.

\section{Anti-Inflammatory activity of EELLI by carrageenan induced paw oedema in wistar albino rats}

In this method, rats were divided into five groups of 10 animals each (Equal number of Male \& Female). All the animals were pretreated with drugs / vehicle 60 minutes before injection of $1 \%$ carrageenan $(0.1 \mathrm{ml})$. Swellings of carrageenan-injected foot were measured at zero, first, second, third, fourth and sixth hour using digital plethysmometer. The right hind paw was injected with $0.1 \mathrm{ml}$ of vehicle. The animals which received indomethacin (10 mg/kg, p.o.) served as reference standard and those which received $1 \%$ gum acacia $3 \mathrm{ml} / \mathrm{kg}$ served as control. Three doses of the test drug were selected $(75,150 \& 300 \mathrm{mg} / \mathrm{kg}$, p.o.) for test group of rats, and all the groups were subjected to screening for anti-inflammatory activity. The peak effect of the carrageenan induced oedema was observed at the $3^{\text {rd }} \mathrm{hr}$ after the injection. Increase in the paw volume at $3^{\text {rd }} \mathrm{hr}$ was calculated as percentage compared with the volume measured immediately after injection of carrageenan for each animal. The data was compared between groups. ${ }^{2}$

\section{Statistical analysis}

Results were expressed as mean \pm SEM. Statistical analysis was performed using one-way analysis of variance (ANOVA) followed by Dunnett's Multiple Comparison test. $\mathrm{P}<0.05$ was considered statistically significant.

\section{RESULTS}

Oral administration of EELLI at doses of $150 \mathrm{mg} / \mathrm{kg}$ and $300 \mathrm{mg} / \mathrm{kg}$ showed significant anti-inflammatory activity with a $\mathrm{p}$ value of $\mathrm{p}<0.01$ and $\mathrm{p}<0.05$ respectively by carrageenan induced paw oedema in wistar albino rats compared to control. The percentage inhibition of the oedema at $3^{\text {rd }}$ hour was $52.58 \%$ and $36.87 \%$ at the dose of $150 \mathrm{mg} / \mathrm{kg}$ and $300 \mathrm{mg} / \mathrm{kg}$ respectively compared to control and standard groups (Table $1 \&$ Figure 1).

Table 1: Anti-inflammatory effect of ethanolic extract of leaves of Leucas indica (EELLI) by carrageenan induced paw oedema in rats (Acute study).

\begin{tabular}{|c|c|c|c|c|c|c|c|}
\hline Drugs & Ohr & $1^{\text {st }} \mathrm{hr}$ & $2^{\text {nd }} \mathrm{hr}$ & $3^{\mathrm{rd}} \mathrm{hr}$ & $4^{\text {th }} \mathrm{hr}$ & $6^{\text {th }} \mathrm{hr}$ & $\begin{array}{l}\% \text { Inhibition } \\
\text { at } 3^{\text {rd }} \mathrm{hr}\end{array}$ \\
\hline $\begin{array}{l}\text { Control }(1 \% \text { Gum } \\
\text { acacia) }(3 \mathrm{ml} / \mathrm{kg}) \text {, p.o }\end{array}$ & $\begin{array}{l}0.49 \pm \\
0.09\end{array}$ & $\begin{array}{l}1.61 \pm \\
0.06\end{array}$ & $\begin{array}{l}1.30 \pm \\
0.13\end{array}$ & $\begin{array}{l}1.41 \pm \\
0.09\end{array}$ & $\begin{array}{l}1.74 \pm \\
0.07\end{array}$ & $\begin{array}{l}1.31 \pm \\
0.10\end{array}$ & - \\
\hline $\begin{array}{l}\text { Indomethacin } \\
10 \mathrm{mg} / \mathrm{kg}, \mathrm{p.o}\end{array}$ & $\begin{array}{l}0.46 \pm \\
0.07\end{array}$ & $\begin{array}{l}0.48 \pm \\
0.05 * * *\end{array}$ & $\begin{array}{l}0.72 \pm \\
0.03 * * *\end{array}$ & $\begin{array}{l}0.30 \pm \\
0.08 * * *\end{array}$ & $\begin{array}{l}0.40 \pm \\
0.10 * * *\end{array}$ & $\begin{array}{l}0.55 \pm \\
0.07 * * *\end{array}$ & 78.72 \\
\hline $\begin{array}{l}\text { EELLI } \\
75 \mathrm{mg} / \mathrm{kg}, \mathrm{p.o}\end{array}$ & $\begin{array}{l}0.60 \pm \\
0.08\end{array}$ & $\begin{array}{l}1.36 \pm \\
0.08 *\end{array}$ & $\begin{array}{l}1.38 \pm \\
0.09 *\end{array}$ & $\begin{array}{l}1.40 \pm \\
0.09 *\end{array}$ & $\begin{array}{l}1.38 \pm \\
0.11 *\end{array}$ & $\begin{array}{l}1.10 \pm \\
0.10^{*}\end{array}$ & 0.70 \\
\hline $\begin{array}{l}\text { EELLI } \\
150 \mathrm{mg} / \mathrm{kg}, \mathrm{p.o}\end{array}$ & $\begin{array}{l}0.54 \pm \\
0.08\end{array}$ & $\begin{array}{l}0.65 \pm \\
0.08 * * *\end{array}$ & $\begin{array}{l}0.79 \pm \\
0.06 * * *\end{array}$ & $\begin{array}{l}0.67 \pm \\
0.11 * * *\end{array}$ & $\begin{array}{l}0.58 \pm \\
0.09 * * *\end{array}$ & $\begin{array}{l}0.72 \pm \\
0.05 * * *\end{array}$ & 52.58 \\
\hline $\begin{array}{l}\text { EELLI } \\
\text { 300mg/kg, p.o }\end{array}$ & $\begin{array}{l}0.57 \pm \\
0.10\end{array}$ & $\begin{array}{l}1.24 \pm \\
0.22 *\end{array}$ & $\begin{array}{l}0.84 \pm \\
0.17 * *\end{array}$ & $\begin{array}{l}0.89 \pm \\
0.18 * *\end{array}$ & $\begin{array}{l}1.24 \pm \\
0.16^{* *}\end{array}$ & $\begin{array}{l}0.97 \pm \\
0.18 * *\end{array}$ & 36.87 \\
\hline
\end{tabular}

$\mathrm{n}=10$. The observation are mean \pm S.E.M. $* \mathrm{p}>0.05, * *<0.05, * * * \mathrm{p}<0.01$ as compared to control (ANOVA followed by Dunnett's multiple comparison test); EELLI- Ethanolic Extract of the leaves of Leucas indica; p.o - per orally 


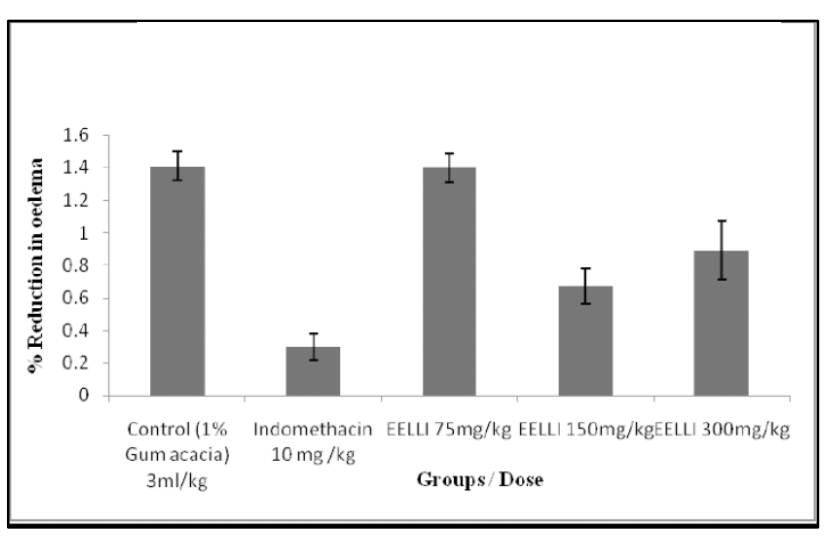

Figure 1: Anti-inflammatory effect of ethanolic extract of leaves of Leucas indica (EFLLI) by carrageenan induced paw oedema in rats at 3rd hour (Acute study).

The observations are mean \pm S.E.M. as compared to control (ANOVA followed by Dunnett's multiple comparison test), EELLI- Ethanolic Extract of the leaves of Leucas indica.

\section{DISCUSSION}

Pain, inflammation and pyrexia are the most usual disturbing symptom in day to day life. Plenty of drugs are available in the market for relieving these symptoms and which are also sold over the counter (OTC). However, they have high tendency of causing adverse drug reaction from a trivial nausea and vomiting to gastric irritation leading to peptic ulcer, perforation and may also even lead to death. ${ }^{3}$ The main undesirable side-effects of aspirin (Irreversible COX inhibitors) taken by oral route are gastrointestinal ulcers, GI bleeding, and tinnitus, especially in higher doses. In children and adolescents, aspirin is no longer indicated to control flu-like symptoms or the symptoms of chickenpox or other viral illnesses, because of the risk of Reye's syndrome. ${ }^{4}$ Reversible COX inhibitors have not shown any superiority over aspirin in therapeutic effects of safety in over dose. Nimesulide has been banned in most western country due to its hepatotoxic effects. Even though paracetamol is commonly prescribed as an analgesic and antipyretic drug, but it lacks anti inflammatory effects and also not safe in over dose. Selective COX 2 inhibitors have been least prescribed in last few years due to its adverse cardiac events and many have been withdrawn from the market. ${ }^{5}$ Corticosteroids have anti inflammatory effects, but lacks analgesic and antipyretic effects. Moreover the long term administration of corticosteroids has its own adverse effects and also delays wound healing process. ${ }^{6,7}$ In recent years, active principles of different chemical structures have been isolated from plants possessing anti-inflammatory activity. Southern part India has a tradition of using herbal preparation from centuries especially in dakshina kannada (Mangalore district, Karnataka, India). However no scientific data are available for many herbal drugs which are locally used. Hence evaluating these herbal drugs, it would be worthwhile to have scientific approach of using them. Hence in this study, an indigenous plant called Leucas indica mentioned in Charaka and Sushruta treaties as an analgesic, anti-inflammatory and antipyretic drug and also in folk medicine was taken to evaluate acute anti-inflammatory activity of EELLI by carrageenan induced paw oedema in Wistar Albino rats. ${ }^{8}$ Oral administration of EELLI at doses of 150 and $300 \mathrm{mg} / \mathrm{kg}$ showed significant anti-inflammatory activity with a $\mathrm{p}$ value of $\mathrm{p}<0.01$ and $\mathrm{p}<0.05$ respectively (Table 1 $\&$ Figure 1). The percentage inhibition of the oedema at $3^{\text {rd }}$ hour was $52.58 \%$ and $36.87 \%$ at the dose of 150 $\mathrm{mg} / \mathrm{kg}$ and $300 \mathrm{mg} / \mathrm{kg}$ respectively (Table $1 \&$ Figure 1 ). Phytochemical studies on EELLI showed the presence of phytosterols, triterpenoids, flavonoids, lactones, fats and fatty acid, glycoside, phenolic compound and tannins. ${ }^{9}$ Phenolic compounds possess biological properties such as antiapoptosis, antiaging, anticancer, anti-inflammatory, antiatherosclerosis, improvement of endothelial function, inhibition of angiogenesis and cell proliferation activities. ${ }^{10}$ Presence of phenolic compounds could be the reason for its anti-inflammatory activity of EELLI.

However, further studies are required to evaluate its comprehensive analysis including quantitative / semi quantitative analysis, characterize its chemical structure and assess its pharmacotherapeutic activities with exact mechanism of action as an anti-inflammatory agent.

\section{Funding: None \\ Conflict of interest: None declared}

Ethical approval: The study was approved by the Institutional Animal Ethical Committee

\section{REFERENCES}

1. Eswaraiah MC, Rahman H, Vakati K. In-Vivo and In-Vitro Anti-Inflammatory Activity of Aquilaria agallocha Oil. Int J Basic Med Sci Pharm (IJBMSP) 2012;2:7-10.

2. Duffy JC, Dearden JC, Rostron C. Design, Synthesis and biological testing of a novel series of antiinflammatory drugs. J Pharm Pharmacol 2001;53:1505-14.

3. Chandrashekar R, Rao SN. Acute Central and Peripheral Analgesic Activity of Ethanolic Extract of The Leaves Of Clerodendrum Viscosum (EECV) In Rodent Models. J Drug Delivery Therap 2012;2:105-8.

4. Macdonald S. Aspirin use to be banned in under 16 year olds. BMJ 2002;325:988.

5. Kearney PM, Baigent C, Godwin J, Halls $\mathrm{H}$, Emberson JR, Patrono C. Do selective cyclooxygenase-2 inhibitors and traditional non-steroidal anti-inflammatory drugs increase the risk of atherothrombosis? Meta-analysis of randomized trials. BMJ 2006;332:1302-8.

6. Mehlisch DR. The efficacy of combination analgesic therapy in relieving dental pain. $\mathrm{J}$ Am Dent Assoc 2002;133:861-71. 
7. Janssen P, Niemegeers CJE, Dony JGH. The inhibitory effect of fentanyl and other morphine like analgesics on the warm water induced tail withdrawal reflex in rats. Arzneim Forsch 1963;13:502-7.

8. Sharma HK, Chhangte L, Dolui AK. Traditional medicinal plants in Mizoram, India. Fitoterapia 2001;72:146-61.
9. Chandrashekar R, Rao SN. Phytochemical analysis of ethanolic extract of leaves of Leucas indica (EELLI). Int J Pharm Bio Sci 2013;4:33-8.

10. Yadav RNS, Agarwala M. Phytochemical analysis of some medicinal plants. J Phytology 2011;3:1014.

doi:10.5455/2319-2003.ijbcp20130613

Cite this article as: Chandrashekar R, Rao SN. Acute anti-inflammatory activity of ethanolic extract of leaves of Leucas indica by carrageenan induced paw oedema in wistar albino rats. Int $\mathrm{J}$ Basic Clin Pharmacol 2013;2:302-5. 